\title{
MONOTONICITY OF SEQUENCES INVOLVING CONVEX AND CONCAVE FUNCTIONS
}

\author{
Chao-Ping Chen, Feng Qi, Pietro Cerone and Sever S. Dragomir
}

Abstract. Let $f$ be an increasing and convex (concave) function on $[0,1)$ and $\phi$ a positive increasing concave function on $[0, \infty)$ such that $\phi(0)=0$ and the sequence $\left\{\phi(i+1)\left(\frac{\phi(i+1)}{\phi(i)}-\right.\right.$ 1) $\}_{i \in \mathbb{N}}$ decreases (the sequence $\left\{\phi(i)\left(\frac{\phi(i)}{\phi(i+1)}-1\right)\right\}_{i \in \mathbb{N}}$ increases). Then the sequence $\left\{\frac{1}{\phi(n)} \sum_{i=0}^{n-1} f\left(\frac{\phi(i)}{\phi(n)}\right)\right\}_{n \in \mathbb{N}}$ is increasing.

Mathematics subject classification (2000): 26D15, 26 A51.

Key words and phrases: Inequality, concave function, monotonicity.

\section{REFERENCES}

[1] H. AlZER, On an inequality of H. Minc and L. Sathre, J. Math. Anal. Appl. 179 (1993), 396-402.

[2] T. H. CHAN, P. GAO AND F. QI, On a generalization of Martins' inequality, Monatsh. Math. (2003), in press. RGMIA Res. Rep. Coll. 4 (2001), no. 1, Art. 12, 93-101. Available online at http://rgmia.vu.edu.au/v4n1.html.

[3] S. S. DRagomir, Some remarks on Hadamard's inequalities for convex functions, Extracta Math. 9 (1994), no. 2, 88-94.

[4] S. S. Dragomir And C. E. M. PeArCe, Selected Topics on Hermite-Hadamard Type Inequalities and Applications, RGMIA Monographs, 2000. Available online at http: //rgmia.vu. edu.au/monographs/hermite_hadamard.html.

[5] N. Elezović And J. PeČArić, On Alzer's inequality, J. Math. Anal. Appl. 223 (1998), 366-369.

[6] B.-N. GuO AND F. QI, An algebraic inequality, II, RGMIA Res. Rep. Coll. 4 (2001), no. 1, Art. 8, 55-61. Available online at http://rgmia.vu.edu.au/v4n1.html.

[7] J.-CH. KuANG, Chángyòng Bùděngshì (Applied Inequalities ), 2nd edition, Hunan Education Press, Changsha, China, 1993. (Chinese)

[8] J.-CH. KuAnG, Some extensions and refinements of Minc-Sathre inequality, Math. Gaz. 83 (1999), 123-127.

[9] J. S. Martins, Arithmetic and geometric means, an applications to Lorentz sequence spaces, Math Nachr. 139 (1988), 281-288.

[10] H. Minc AND L. SATHRE, Some inequalities involving $(n !)^{1 / r}$, Proc. Edinburgh Math. Soc. 14 (1964/65), 41-46.

[11] D. S. Mitrinović, J. E. Pečarić and A. M. Fink, Classical and New Inequalities in Analysis, Kluwer Academic Publishers, Dordrecht/Boston/London, 1993.

[12] N. Ozeki, On some inequalities, J. College Arts Sci. Chiba Univ. 4 (1965), no. 3, 211-214. (Japanese)

[13] F. QI, An algebraic inequality, J. Inequal. Pure Appl. Math. 2 (2001), no. 1, Art. 13. Available online at http: //jipam.vu.edu.au/v2n1/006_00.html. RGMIA Res. Rep. Coll. 2 (1999), no. 1, Art. 8, 81-83. Available online at http://rgmia.vu.edu.au/v2n1.html.

[14] F. QI, Generalization of H. Alzer's inequality, J. Math. Anal. Appl. 240 (1999), 294-297.

[15] F. QI, Generalizations of Alzer's and Kuang's inequality, Tamkang J. Math. 31 (2000), no. 3, $223-227$. RGMIA Res. Rep. Coll. 2 (1999), no. 6, Art. 12. Available online at http://rgmia.vu.edu.au/v2n6.html. 
[16] F. QI, Inequalities and monotonicity of sequences involving $\sqrt[n]{(n+k) ! / k !}$, RGMIA Res. Rep. Coll. 2 (1999), no. 5, Art. 8, 685-692. Available online at http://rgmia.vu.edu.au/v2n5.html.

[17] F. QI AND L. DEBNATH, On a new generalization of Alzer's inequality, Internat. J. Math. Math. Sci. 23 (2000), no. 12, 815-818.

[18] F. QI AND B.-N. GUO, An inequality between ratio of the extended logarithmic means and ratio of the exponential means, Taiwanese Journal of Mathematics 7, No 2 (2003), in press.

[19] F. QI AND B.-N. GUO, Monotonicity of sequences involving convex function and sequence, RGMIA Res. Rep. Coll. 3 (2000), no. 2, Art. 14, 321-329. Available online at http://rgmia.vu.edu.au/v3n2.html.

[20] F. QI AND Q.-M. LuO, Generalization of H. Minc and J. Sathre's inequality, Tamkang J. Math. 31 (2000), no. 2, 145-148. RGMIA Res. Rep. Coll. 2 (1999), no. 6, Art. 14, 909-912. Available online at http://rgmia.vu.edu.au/v2n6.html.

[21] J. SÁNDOR, On an inequality of Alzer, J. Math. Anal. Appl. 192 (1995), 1034-1035.

[22] J. SÁNDOR, Comments on an inequality for the sum of powers of positive numbers, RGMIA Res. Rep. Coll. 2 (1999), no. 2, 259-261. Available online at http: //rgmia.vu.edu.au/v2n2 .html.

[23] N. TowgHI, Notes on integral inequalities, RGMIA Res. Rep. Coll. 4 (2001), no. 2, Art. 10. Available online at http://rgmia.vu.edu.au/v4n2.html.

[24] N. TowghI AND F. QI, An inequality for the ratios of the arithmetic means of functions with a positive parameter, RGMIA Res. Rep. Coll. 4 (2001), no. 2, Art. 15, 305-309. Available online at http://rgmia.vu.edu.au/v4n2.html.

[25] J. S. UME, An elementary proof of H. Alzer's inequality, Math. Japon. 44 (1996), no. 3, 521-522.

[26] F. QI, On a new generalization of Martin's inequality, RGMIA Res. Rep. Coll. 5 (2002), no. 3, Art. 13. Available online at http://rgmia.vu.edu.au/v5n3.html. 